\title{
Skills required to deliver energy efficient school retrofit buildings
}

Article

Accepted Version

Bevan, W., Lu, S.-L. and Sexton, M. (2020) Skills required to deliver energy efficient school retrofit buildings. Engineering, Construction and Architectural Management, 27 (10). pp. 3051-3073. ISSN 0969-9988 doi: https://doi.org/10.1108/ECAM-03-2019-0126 Available at https://centaur.reading.ac.uk/90801/

It is advisable to refer to the publisher's version if you intend to cite from the work. See Guidance on citing.

To link to this article DOI: http://dx.doi.org/10.1108/ECAM-03-2019-0126

Publisher: Emerald

All outputs in CentAUR are protected by Intellectual Property Rights law, including copyright law. Copyright and IPR is retained by the creators or other copyright holders. Terms and conditions for use of this material are defined in the End User Agreement.

\section{www.reading.ac.uk/centaur}

\section{CentAUR}

Central Archive at the University of Reading 
Reading's research outputs online 


\title{
Skills required to deliver energy efficient school retrofit buildings
}

\begin{abstract}
Purpose: The prevailing literature argues the need for 'new' skills to deliver energy efficient buildings. The concept of new skills, however, has not been subject to empirical investigation. This paper aims to provide insight on the required new skills, and their development and application, for the successful delivery of energy efficient school retrofit buildings.
\end{abstract}

Design/methodology/approach: The research employed a case study approach of a school retrofit building project in the early stages of the adoption of energy efficient measures. Through the application of the socio-technical network approach (STNA) as data collection and analysis framework, data were collected through semi-structured interviews, observations and a review of relevant organisational documentation and were analysed using thematic coding.

Findings: The findings reveal key actors (i.e. the local authority, energy contractors and school end-users), their principal interests and the required communication, project management, energy management, technical and research skills during their interactions in the successful delivery of the school retrofit building project. Results further reinforce the crucial role of the local authority in driving energy performance improvement of school buildings.

Originality / value: This study demonstrates empirical evidence of the principal actors and skills required for the delivery of energy efficient school retrofit buildings, contributes to new theoretical insights at the identification of key micro-level development of construction skills through the project network, and evidences on how the STNA can be mobilised in construction skills research.

Key words: energy efficient measures (EEM), energy efficient school buildings, new skills, skill development, socio-technical network approach (STNA)

\section{Introduction}

The United Kingdom (UK) government is committed to reduce greenhouse gas emissions by at least $80 \%$ by 2050 compared to 1990 levels (Climate Change Act 2008) and to the creation of a low carbon economy (DECC 2011). Buildings account for approximately $34 \%$ of the UK's greenhouse gas emissions (Committee on Climate Change 2015). Any improvement in the energy performance of buildings, therefore, can significantly contribute to the delivery of a low carbon economy. A number of the UK policies designed to reduce consumption and improve efficiency in business/industry have been introduced. The Building Regulations (more 
[To cite this article: Bevan, W., Lu, S. and Sexton, M.G. (2020), "Skills required to deliver energy efficient school retrofit buildings", Engineering, Construction and Architectural Management, DOI: 10.1108/ECAM-03-2019-0126]

specifically, Part L - Heat and Power) encourage the construction sector to consider energy production and energy consumption within buildings (NHBC 2014). The prevailing literature has stressed that the delivery of energy efficient buildings requires a new set of 'green' skills for the design (RIBA 2008), construction and post-completion stages (Home Building Skills 2013). The need for 'new' skills is a common recommendation in the construction literature (Construction Skills 2010, Home Building Skills 2013).

Prior research on the required skills to deliver energy efficient buildings has focused primarily on either gaining new skills or enhancing existing skills, in order to address the challenge of 'skills gaps' within the construction industry (GCB 2015). Training and education of the workforce is argued to be the way forward to address the 'skills gaps' challenge (e.g. Construction Skills 2010). Furthermore, the literature suggests the need for an integrated approach to skills' development (RIBA 2015), whereby recognition and participation is required by key project stakeholders such as employees, employers, manufacturers and suppliers (Gann and Senker 1998, Grugulis 2003). Construction Skills (2010) further expand the agenda on skill development by the inclusion of key government, professional bodies and sector skills councils within the industry. Therefore, the use of training to gain new skills or enhance existing skills is linked to the involvement of the construction workforce and its clients, indicating the necessity of interactions and negotiations between key project stakeholders. The stakeholder approach advocated implies actors' interests influence and condition the skills requirements during the interactions.

The extant literature provides useful normative, albeit often vague, description of skills and policy approaches. However, that literature is invariably silent on what these new skills actually are, how they are developed and how they are applied in practice. As a result, there are only partial insights on how the construction sector and its clients can respond to the skills challenges (Construction Skills 2011) and, if the need for new skills does exist, what action is 
[To cite this article: Bevan, W., Lu, S. and Sexton, M.G. (2020), "Skills required to deliver energy efficient school retrofit buildings", Engineering, Construction and Architectural Management, DOI: 10.1108/ECAM-03-2019-0126]

required to obtain them. The aim of this paper is to provide insight on the required new skills, and their development and application, for the successful delivery of energy efficient school retrofit buildings. The research adopts a socio-technical network approach (STNA) (Elzen et al. 1996, Schweber and Harty 2010) which highlights key actors, and their interests, interactions and negotiations, within the network.

The research contribution is significant in four respects. First, it presents empirical evidence of the required skills, and their development and application in practice for the delivery of energy efficient buildings. Second, it provides new theoretical insights into the micro-level development of construction skills. Third, it demonstrates the value of the STNA as a potential research method to recognise the principal interests of actors and the acting spaces through which these interests are negotiated and, ultimately, shaped or displaced through the process. Finally, the results reinforce the crucial role of the local authority in the retrofit of school buildings to improve energy efficiency.

\section{Research framing}

In the construction literature there is strong agreement that the sector suffers from 'skills shortages' (Smith 2019) and 'skills gaps' (Construction Skills 2010). More specific to the delivery of energy efficient buildings, there have been calls for 'new' skills (Construction Skills 2010), which have also been described as 'green' skills and 'low carbon' skills (RIBA 2008, Jagger et al. 2012). The type of skills required, the skill definitions and ideas around what the skills actually consist of, however, are vague (Chan and Dainty 2007). The lack of clarity associated with skills can be due to the diversity of the skill challenges within the construction sector (Dainty et al. 2004), uncertainty surrounding skill development (Dainty et al. 2005) and complexity of skill assessment (Chan and Dainty 2007). To address this problem, there is a 
[To cite this article: Bevan, W., Lu, S. and Sexton, M.G. (2020), "Skills required to deliver energy efficient school retrofit buildings", Engineering, Construction and Architectural Management, DOI: 10.1108/ECAM-03-2019-0126]

need for a 'socio-cultural' understanding or 'socialisation' of skills (Chan and Dainty 2007).

In much the same vein, an approach is required that studies the skills challenges and possible solutions, through the analysis of a diverse range of actors within the construction sector (Dainty et al. 2004). To highlight the skills issues, understand what the necessary skills actually consist of, and how the construction sector and its clients can obtain them, an integrated approach is required (Glass et al. 2008). In the following, the concept and classification of 'skills' is briefly introduced first, followed by a review of the relevant literature to explore the skills challenges associated with the delivery of energy efficient buildings. This section ends with the adoption of energy efficient measures for building energy reduction.

\section{Concept and classification of skills}

A skill is connected to the ability, competence and knowledge (Carroll and Boutall 2011), to utilise specific tools for the role (Construction Skills 2011) or further relate to a specific role within the workplace (CBI 2013). Clarke et al. (2013) extend this idea and argue that a skill can be defined through evidence of an individual's attributes, qualifications, knowledge and experience of the occupation required to be undertaken.

In broad terms, two skill classifications are evident within the literature: 'generic' versus 'specialist' and 'existing' versus 'new'. The classification boundaries are not definite and there are particular skills that may be included in both classifications. In the first classification of generic versus specific skills, 'generic' skills are those which are not specific to a particular subject domain (e.g. industry sector) and can cover a wide area of diverse skills (UKCES 2009). For example, 'generic' skills are categorised as numerical skills, professional communication skills, problem solving skills and computer skills (Felstead et al. 2012), as well as 'employability' skills (UKCES 2009) such as interpersonal skills (communication, team work, ability to negotiate) and the ability to use technology (OECD 2011). The concerns of the CIOB 
[To cite this article: Bevan, W., Lu, S. and Sexton, M.G. (2020), "Skills required to deliver energy efficient school retrofit buildings", Engineering, Construction and Architectural Management, DOI: 10.1108/ECAM-03-2019-0126]

Education Framework (CIOB 2010), who as a professional body, state the need to improve education to reduce the construction sector skills gap, are primarily linked to the lack of generic skills and the emphasis on employability skills by Construction Management graduates (Rawlins and Marasini 2011). In comparison, 'specialist' skills are connected to activities that are associated with individuals who are highly skilled in a specific field (Edum-Fotwe and McCaffer 2000). The second classification is 'new' versus 'existing' skills. 'New' skills are primarily related to an 'up-skilling' of the workforce to undertake new roles within the workplace and the use of more advanced equipment (HM Government 2010). 'Existing' skills are described as those that an individual / workforce already possesses, but can also be referred to in connection with the requirement for training to enhance these skills.

\section{Skill challenges for the delivery of energy efficient buildings}

There is a need for new skills, which have been referred as 'green' skills and 'low carbon' skills (Jagger et al. 2012), in relation to the energy efficient building design and construction (Home Building Skills 2013) and for clients during the delivery of energy efficient buildings (SDC 2010). Green skills can be linked to the adoption of technology within buildings (Aldersgate Group 2009). The report of 'No more lost generations' prepared by the CIOB and CITB for the House of Commons (2014), for example, emphasises that the skills challenges for the delivery of energy efficient buildings is likely to involve skills issues with the adoption of new technologies. To add to the confusion, a green skill has been classified as both 'generic' (Bird and Lawton 2009) and 'specialist' (Energy UK 2014) in nature, where there are indications the workforce require the aid of training to achieve green skills. Similarly, a degree of uncertainty is associated with the idea of low carbon skills. Low carbon skills refer to a combination of skills and knowledge required that focus solely on the design stages (RIBA 2008). There are further reports that refer low carbon skills to the entire life-cycle and use of energy efficient buildings (Construction Skills 2011). Much the same as for green skills, low 
[To cite this article: Bevan, W., Lu, S. and Sexton, M.G. (2020), "Skills required to deliver energy efficient school retrofit buildings", Engineering, Construction and Architectural Management, DOI: 10.1108/ECAM-03-2019-0126]

carbon skills include reference to the requirement of both 'new' and 'existing' skills for the construction sector and its clients, but little information on how to gain the new skills (HM Government 2010). Although the prevailing research states a need for skills for energy efficient buildings, it simply states the need for an 'up-skilling' or 're-skilling' of the construction workforce to provide energy efficient measures within buildings (e.g. GCB 2013) (see 'the adoption of energy efficient measures for building energy reduction' section below for further details). There is no definitional clarity, however, of green or low carbon skills. As a consequence of the diverse views, complications arise with regards to understanding the exact meaning and type of skills associated with the green skills classification.

\section{Skill development}

In an attempt to engage in the skills issue, the prevailing literature has made in-roads into understanding the possible routes to skill enhancement for the construction industry (Clarke and Wall 1998, Johari and Jha 2020). Key discussions tend to be associated with the dominant means of training, mainly apprenticeships and formal qualifications (e.g. National Vocational Qualifications) (Brockman et al. 2008, Smith 2019), the type of skills desired (e.g. the move away from 'craft' skills), the effective outcome of attempts to develop construction skills (Hogarth and Gambin 2014) and the challenges towards the adoption of training and skill development (Johari and Jha 2020). Recommendations for retrofit energy efficient buildings in particular suggest that involvement is required by the entire supply chain, in addition to cooperation with government and training bodies in order to gain the necessary skills and knowledge (Construction Skills 2010).

\section{The adoption of energy efficient measures for building energy reduction}

The energy efficient measures (EEMs) are predominantly advised as the initial methods for adoption in buildings to reduce energy consumption and key to improve energy performance 
[To cite this article: Bevan, W., Lu, S. and Sexton, M.G. (2020), "Skills required to deliver energy efficient school retrofit buildings", Engineering, Construction and Architectural Management, DOI: 10.1108/ECAM-03-2019-0126]

(EST 2010). To provide greater understanding of the skill sets that may be required by actors within the investigation, it will be of value to explain how energy reduction can be achieved through the adoption of EEM. An EEM is a method or device that can be adopted to save energy within a building (The Carbon Trust 2015), which can include a type of fabric or technology applied to the building, or the adoption of behavioural change for building occupants (EST 2017). More specifically, the adoption of EEMs is often referred to as the 'fabric first' approach (EST 2010) prior to the use of more complex technologies. The prevailing literature argue that the adoption of EEMs within buildings come with many challenges. One of these is little understanding of the more appropriate EEMs in buildings in general, and in existing buildings more specifically (Centre for Low Carbon Futures 2012). The complexity associated with the selection of EEMs in existing buildings is further emphasised, where a range of measures are explored and understood in relation to building energy consumption, including energy efficient lighting, double glazed windows (Pisello 2012), thermal insulation (Huang et al. 2013) and end-user education/behaviours (Azizi et al. 2015). The appropriate EEM for the existing buildings appears to be connected to the energy saving potential of the measure, the cost or economics of the measure (Ma et al. 2012), the enduser preferences of the measure and the building (building type, age and location) for the retrofit project.

\section{Research design and methods}

\section{Empirical setting}

The research investigates the retrofit of a school building to improve its energy efficiency. Schools represent some of the most important of our civic buildings. There is a need to ensure the school building create learning environments which are equipped with appropriate learning 
[To cite this article: Bevan, W., Lu, S. and Sexton, M.G. (2020), "Skills required to deliver energy efficient school retrofit buildings", Engineering, Construction and Architectural Management, DOI: 10.1108/ECAM-03-2019-0126]

conditions and suitable teaching environments for students and staff. However, according to the RIBA (2014), of the 29,000 schools in Britain, $80 \%$ of the stock is in poor condition and inadequately maintained. RIBA (2016) further goes on to argue more specifically, schools are failing on energy performance due to issues with inefficient operating performance. This places the existing school stock very much a priority in terms of energy improvement, which extends to be of benefit to the school in terms of running costs, the creation of a suitable working place for staff and students, in addition to environmental benefits, e.g. carbon emission reduction. In order to improve the energy performance of school buildings, those undertaking the retrofit will need an understanding and ability to evaluate the types of methods available to achieve building energy reduction. The skills attained by the actors carrying out the retrofit for the energy efficient building may influence the outcome of the project.

The principal actor to improve energy performance are the local authorities (LAs) as they own and are responsible for school buildings. A stringent current UK strategy aims to enhance the energy efficiency of buildings with the implementation of the National Energy Efficiency Action Plan, which encourages LAs to initiate building energy performance through Retrofit Action Plans (RIBA 2014). The plans for local government are connected to the wider carbon emission reduction targets, such as the requirement to reduce $80 \%$ carbon dioxide emission reduction by 2050 (Climate Change Act 2008), along with demands to encourage sustainability within the built environment and construction industry. Indeed, demands are placed on the LA to reduce the energy consumption of buildings that they own and are responsible for, including school properties (Carbon Trust 2012), such as the assessment and display of Display Energy Certificates (DEC) (DCLG 2015). Furthermore, the 'leadership' role LAs has been advocated to promote sustainability (UK Green Building Council 2017) and sustainable buildings (Li et al. 2019). LAs, therefore, play a crucial role in driving energy performance improvement of school buildings. 
[To cite this article: Bevan, W., Lu, S. and Sexton, M.G. (2020), "Skills required to deliver energy efficient school retrofit buildings", Engineering, Construction and Architectural Management, DOI: 10.1108/ECAM-03-2019-0126]

\section{The case study}

A case study approach was adopted of a school retrofit project in the south east of England.

The school retrofit, which was in the initial stages of the adoption of EEMs, was selected for three reasons. First, the operations and logistics surrounding schools and the development of facilities are unique to other buildings (e.g. diverse occupancy times, a variety of end-users occupying the building and the LA procurement process). Second, the project was identified by the LA deemed as an 'emergency building' (i.e. the building had a high energy consumption and had the least EEMs within LA's school building stock). Finally, a range of EEMs from fabric measures (e.g. insulation) to renewable technology (e.g. solar PV) had been adopted or in the process of adoption. This provided the empirical space to investigate the adoption of various EEMs, offer insights into the skills required during the project delivery, and allow an investigation into a variety of roles and interactions within the supply chain involved in the school retrofit project. Furthermore, by gaining insight into the interactions, negotiations and exchanges by the key stakeholders involved in the project, details of the skills required during the project delivery and potential areas for training were evidenced.

\section{Framework for data collection and analysis: socio-technical network approach}

A STNA (Elzen et al. 1996) was adopted as a data collection and analysis framework for the research, which guided the empirical work and provided a lens to understand the identification, development and use of the required skills to deliver the school retrofit building project. The STNA investigates a 'social' network of actors that allows the identification of key actors / actor groups, along with their interests, interactions and negotiations. In regards to the selection of this method and its applicability for this research, the socio-technical approach is consistent with Clarke et al.'s (2017: 37) call that if the construction sector is to transit to low energy, one needs to recognise the incorporation of renewable technologies into a building element (e.g. 
[To cite this article: Bevan, W., Lu, S. and Sexton, M.G. (2020), "Skills required to deliver energy efficient school retrofit buildings", Engineering, Construction and Architectural Management, DOI: 10.1108/ECAM-03-2019-0126]

the building envelope) "as made of elements that come together through the social interaction of different occupations ... this implies a socio-technical transition framework encompassing both the material and social worlds." The need of a socio-technical approach is coined by Lowe et al. (2018: 472) who observed the retrofit practice as "a social-technical phenomenon that is co-constituted through material arrangements, actions and meanings." Since the study of interaction between the material and social worlds is the way forward, the STNA is a suitable research method as it recognises the principal interests of actors and the acting spaces through which these interests are negotiated and, ultimately, shaped or displaced through the process of the energy efficient building delivery. In addition to gaining information on the social and material entities within the project, the STNA provided information in relation to actor / actor group interests and negotiations. These negotiations gave insight of potential mechanisms to facilitate (actor) skill development for the project delivery, which can aid the transition, discussed by Clarke et al. (2017). The application of this approach also provided a bounded network during data collection, the STN - a term which describes the relationship between the social and the technical (e.g. Callon et al. 1986, Latour 1993, Law and Hassard 1999) and its defining feature is in the separation of social and technical entities. The boundary of the network and guidance through the identification of key actors / actor groups supported data collection within the study.

Previous studies have employed the STNA within construction management research. Downey (2014), for example, investigated how low and zero carbon technologies (e.g. solar PV) are selected and adopted by house builders. Using this approach to mobilise data collection, Downey (2014) highlights the value of the STN to identify the project network and create a required boundary for the research. More broadly, Schweber and Harty (2010) demonstrated the potential value of STN analysis within appropriate construction management research, in addition to how the network may shape the technology adopted in the construction sector. 
[To cite this article: Bevan, W., Lu, S. and Sexton, M.G. (2020), "Skills required to deliver energy efficient school retrofit buildings", Engineering, Construction and Architectural Management, DOI: 10.1108/ECAM-03-2019-0126]

The key concepts of STNA that are to be identified and understood during its adoption consist of artefacts, nodes, intermediaries and interpretative flexibility (Elzen et al. 1996) which are briefly described below:

- Artefacts can be physical / material objects, non-physical actions or a mixture of both physical and non-physical elements within the delivery of energy efficient building network.

- Nodes are actors or groups of actors who are actively involved within the network.

- Intermediaries can be viewed as exchanges that occur between actors (nodes) within the network. Intermediaries can be both tangible (e.g. emails of contracts) and intangible (e.g. conversations relating to meetings / actions) elements within the network.

- Interpretative flexibility relates to how individual actors or group of actors can have different interpretations or meanings attached to the given artefact within the network. Borrowed from SCOT (social construction of technology), the artefact is socially constructed and interpreted by the relevant social groups within the network, as oppose to the relation to features of the artefact (Elle et al. 2010). It is the contrasting interests and interpretations of actors that give rise to negotiations within the network (Klein and Kleinman 2002).

\section{Data collection and analysis}

Three datasets were collected: eleven semi-structured interviews, seven observations that consisted of project meetings with the local authority, energy contractors and school end-users, school building energy audits and EEM installations for the retrofit of the building, along with a review of relevant organisational documentation. University ethics approval was secured prior to data collection. First, prior to interviews, an interview protocol was prepared and pretested. The interview protocol consisted of three sections: (a) an introduction to become 
[To cite this article: Bevan, W., Lu, S. and Sexton, M.G. (2020), "Skills required to deliver energy efficient school retrofit buildings", Engineering, Construction and Architectural Management, DOI: 10.1108/ECAM-03-2019-0126]

familiar with each actor role within the school retrofit project, (b) a main body that discussed the primary actions surrounding the project and skills required, and (c) a closing of the interview that linked questions to further actions for the retrofit project or actor skill development, reiterated what had been discussed during the interview and provided the interviewee (actor) an opportunity to add further insight or ask the interviewer questions in regards to the project. Table 1 below shows the profile of interviewees and their associated key actor groups. Interviews started with the LA energy team, who were the drivers of the delivery of the school retrofit project to meet LA's energy reduction targets. Interviews with the LA energy team offered background information on the project, the EEM adoption process, the required skills for the project and further actors involved in the project network. Actors identified by the LA for further interviews being conducted with were the school staff (i.e. school end-users), two EEM surveyors, one electrical engineer, one solar PV operations manager and one solar PV sales manager (see Table 1). Second, observations were carried out during EEM on-site installation and within project meetings. The focus of observations concentrated on the actions and challenges associated with the adoption of the EEMs (e.g. loft insulation survey and energy efficient lighting installation). Finally, relevant organisational documentation was collected to complement the findings drawn from interviews and observations. Indicative examples included the LA's requirements for energy efficient buildings (such as the LA Carbon Management Plan) providing fuller details on the LA energy targets (i.e. LA's interest); financial aids provided by government illustrating the meaning of energy management skills; information on EEM adoption explaining why certain EEMs were adopted compared to others; and, EEM handover guides for end-users providing details on how school staff operate the EEM.

NVivo 10 (QSR International 2017) was used to analyse the data (i.e. interview transcripts, field notes, organisational documents, images and audio files), and then to identify themes and 
[To cite this article: Bevan, W., Lu, S. and Sexton, M.G. (2020), "Skills required to deliver energy efficient school retrofit buildings", Engineering, Construction and Architectural Management, DOI: 10.1108/ECAM-03-2019-0126]

subthemes from the data collected (Bryman 2016). Guided by the research aim and objectives, key themes that emerged within the interview data were coded. Similarly, relevant observation data was coded using the themes for further detail and to complement the findings from the interviews. The key themes and coding of data offered insight into the actor interests and actor interactions surrounding the delivery of the energy efficient building project. Three 'levels' were used to code the data within Nvivo as representation of actors / actor groups (level 1) identified from the STN, the actors' interests (level 2) indicated by interactions within the STN and the skills employed by actors / actor groups (level 3) revealed by negotiations in the STN surrounding the delivery of the school retrofit building project. These three levels provided sufficient representation of the network surrounding the project, met the research aims, along with the detail for actor /actor group identification, interests and negotiations surrounding the delivery of the project. Figure 1 shows the school retrofit project STN diagram. 
[To cite this article: Bevan, W., Lu, S. and Sexton, M.G. (2020), "Skills required to deliver energy efficient school retrofit buildings", Engineering, Construction and Architectural Management, DOI: 10.1108/ECAM-03-2019-0126]

Table 1: Profile of interviewees for the school retrofit project

\begin{tabular}{|c|c|c|c|}
\hline $\begin{array}{l}\text { Key actor } \\
\text { groups }\end{array}$ & Key actors & Interviewees & Interviewee's role, responsibility and experience \\
\hline \multirow[t]{2}{*}{$\begin{array}{l}\text { Local } \\
\text { authority } \\
\text { (LA) }\end{array}$} & \multirow[t]{2}{*}{$\begin{array}{l}\text { [1] LA energy } \\
\text { team }\end{array}$} & LA energy officer & $\begin{array}{l}\text { The supervision of the energy team; and the project } \\
\text { management of the energy efficient building school retrofit } \\
\text { project and responsible for key decisions surrounding the } \\
\text { project (e.g. funding allocation and the hiring of energy } \\
\text { contractors). } 15 \text { years experience within sustainability in the } \\
\text { built environment and renewable technology. }\end{array}$ \\
\hline & & $\begin{array}{l}\text { LA energy } \\
\text { assistant }\end{array}$ & $\begin{array}{l}\text { The day-to-day contact with the school end-users to monitor } \\
\text { building energy use, the coordination of the energy contractors } \\
\text { for EEM implementation, and the conduction of an energy audit } \\
\text { of the building for potential EEM adoption. } 5 \text { years experience } \\
\text { working within this role. }\end{array}$ \\
\hline \multirow[t]{6}{*}{$\begin{array}{l}\text { Energy } \\
\text { contractors }\end{array}$} & \multirow{2}{*}{$\begin{array}{l}\text { [5] Energy } \\
\text { efficient } \\
\text { measure [EEM] } \\
\text { surveyor }\end{array}$} & $\begin{array}{l}\text { EEM surveyor } \\
\text { (insulation) }\end{array}$ & $\begin{array}{l}\text { The surveying of the building for insulation requirements (i.e. } \\
\text { pre-existing insulation), and communication with the EEM } \\
\text { installers and suppliers. }\end{array}$ \\
\hline & & $\begin{array}{l}\text { EEM surveyor } \\
\text { (solar } \\
\text { photovoltaics: } \\
\text { solar PV) }\end{array}$ & $\begin{array}{l}\text { The assessment for the potential for solar PV adoption and } \\
\text { building electricity generation, and communication to the EEM } \\
\text { installer. Over } 20 \text { years experience within the building sector } \\
\text { and adoption of renewable technology. }\end{array}$ \\
\hline & $\begin{array}{l}\text { [5] EEM } \\
\text { surveyor \& [6] } \\
\text { EEM installer }\end{array}$ & $\begin{array}{l}\text { Electrical } \\
\text { engineer } \\
\text { (lighting) }\end{array}$ & $\begin{array}{l}\text { The organisation and conduction of an energy audit of the } \\
\text { building, the supply of EEM materials and the EEM installation } \\
\text { within the building. }\end{array}$ \\
\hline & \multirow[t]{2}{*}{$\begin{array}{l}\text { [6] EEM } \\
\text { installer }\end{array}$} & $\begin{array}{l}\text { Operations } \\
\text { manager (solar } \\
\text { PV) }\end{array}$ & $\begin{array}{l}\text { The supervision and control of the EEM adoption process during } \\
\text { the implementation and post-completion stages, such as the } \\
\text { supply of EEM handbooks and end-user guides. }\end{array}$ \\
\hline & & $\begin{array}{l}\text { EEM installer } \\
\text { (glazing) }\end{array}$ & $\begin{array}{l}\text { The design and the installation of the double glazed windows } \\
\text { for the building. } 15 \text { years within the glazing industry. }\end{array}$ \\
\hline & $\begin{array}{l}\text { [7] EEM } \\
\text { supplier }\end{array}$ & $\begin{array}{l}\text { Sales manager } \\
\text { (solar PV) }\end{array}$ & $\begin{array}{l}\text { The supply, and primary contact, of appropriate and selected PV } \\
\text { technology to the building (i.e. communication with the PV } \\
\text { installer / surveyor), and the organisation of supply of PV } \\
\text { technology for the project. Over } 10 \text { years sales experience in the } \\
\text { solar PV industry and an extensive knowledge of solar PV. }\end{array}$ \\
\hline \multirow[t]{2}{*}{$\begin{array}{l}\text { School } \\
\text { end-users }\end{array}$} & \multirow[t]{2}{*}{$\begin{array}{l}\text { [2] School end- } \\
\text { users }\end{array}$} & $\begin{array}{l}\text { School business } \\
\text { manager }\end{array}$ & $\begin{array}{l}\text { The primary contact for the school regarding the EEM adoption } \\
\text { process and the involvement in key decisions of the EEM, } \\
\text { particularly in terms of finance availability. }\end{array}$ \\
\hline & & $\begin{array}{l}\text { School site } \\
\text { controller }\end{array}$ & $\begin{array}{l}\text { The planning, implementation and post completion of the EEM } \\
\text { within the school building, and communication with the local } \\
\text { authority and energy contractors during the EEM adoption. } \\
\text { Over } 20 \text { years working in the facility management role for the } \\
\text { school. }\end{array}$ \\
\hline
\end{tabular}


[To cite this article: Bevan, W., Lu, S. and Sexton, M.G. (2020), "Skills required to deliver energy efficient school retrofit buildings", Engineering, Construction and Architectural Management, DOI: 10.1108/ECAM-03-2019-0126]

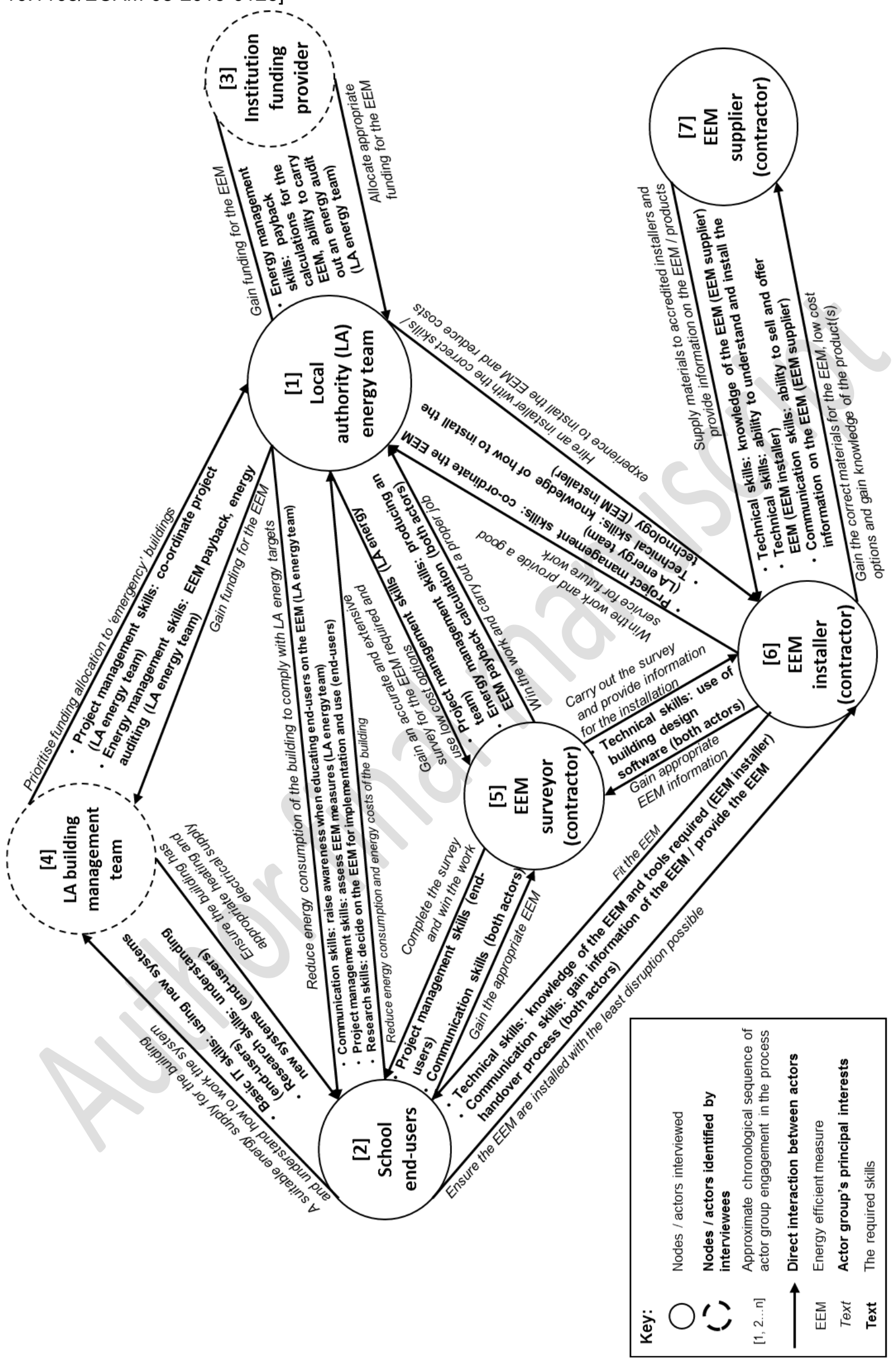

Figure 1. The socio-technical network (STN) for the school retrofit project 
[To cite this article: Bevan, W., Lu, S. and Sexton, M.G. (2020), "Skills required to deliver energy efficient school retrofit buildings", Engineering, Construction and Architectural Management, DOI: 10.1108/ECAM-03-2019-0126]

\section{Limitations of a single case study}

There are criticisms over the use of a single case study (Hammersley and Gomm 2000). This research adopted Yin's (2018) assumption that generalisations that are analytical are acceptable. This view echoes Hammersley and Gomm's (2000) suggestion that the researcher should aim to reveal unique qualities of a case, to reduce the possibility of generalising the data. To encourage the applicability and credibility of the case study findings (Lincoln and Guba 2000), the important emphasis is given to the processes undertaken within the research, which are required to be valid (Guba and Lincoln 1981), rather than testing and assessing the research's validity and reliability (Allard-Poesi et al. 2001).

\section{Key results}

\section{Description of the case study}

The case study is a retrofit of a primary school of 394 pupils, which has one permanent building and two temporary buildings. The permanent building has cavity wall insulation and a solar photovoltaic (PV) array. Due to the need to meet LA energy reduction targets (i.e. $15 \%$ by 2015 and $40 \%$ by 2050 from the 2005 baseline), energy audits were carried out within a number of LA owned schools within the region by the LA energy assistant. Energy efficient lighting, double-glazing and a half-hourly meter were installed within the school building, along with the provision of energy education to the school end-users. During the nine months of data collection, cavity wall and loft insulation surveys were also carried out and suggested as a potential further EEM for adoption within the existing building.

\section{Energy efficient building project's socio-technical network}


[To cite this article: Bevan, W., Lu, S. and Sexton, M.G. (2020), "Skills required to deliver energy efficient school retrofit buildings", Engineering, Construction and Architectural Management, DOI: 10.1108/ECAM-03-2019-0126]

The energy efficient building project's STN can be briefly described in four stages: planning, design, implementation and post-completion. It is difficult to identify the distinct boundaries of the stages within the STN. There is, however, relationships between key actors / actor groups involved within each stage, specific to certain stages (e.g. the EEM installer during the implementation stage) and present throughout a number of stages (e.g. the LA energy team during the planning, design and post-completion stages). The planning stage involved contact to the school by the LA energy team to organise an energy audit and discuss the possibility of EEM adoption. Following an energy audit, the type of EEM adoption within the building was decided upon. The design stage involved the LA energy team to assess, identify and appoint the appropriate energy contractors for the work. Energy contractors were chosen primarily on the lowest price, the perceived quality of work and reliability. Both the design and implementation stages required the energy contractors to assess the proposed EEM, and further carry out EEM installations. The post-completion stage consisted of a handover by the EEM installer to the school end-users, which involved the provision of instructions for the use and operation of the EEM. All stages of the energy efficient building project required communication and co-operation by the network of actors involved in the project.

Figure 1 illustrates the STN for the school retrofit project. It is important to note that actor groups' entry into the network was given a single number in chronological order; [1], [2] or [3] etc. The rationale for this is to enhance the clarity of the story line.

The findings indicate that there are seven principal actors within the network, where each actor group had a specific role(s) during the delivery of the project. Further, there were ten main interactions occurring between the principal actor groups, such as the interaction between the LA energy team [1] and school end-users [2]. The interactions demonstrated the interests of the actors and negotiations surrounding the delivery of the project, which were evidenced during interviews, observations and a review of relevant organisational documentation. The 
[To cite this article: Bevan, W., Lu, S. and Sexton, M.G. (2020), "Skills required to deliver energy efficient school retrofit buildings", Engineering, Construction and Architectural Management, DOI: 10.1108/ECAM-03-2019-0126]

identification of actors' interests and negotiations further provides indication of potential mechanisms to facilitate actors' skill development and / or identified their skills gaps for the delivery of the project. Taking an interaction between the LA energy team [1] and school endusers [2] as an example (see Figure 1), the principal interest of the LA energy team [1] was to 'reduce energy consumption of the building to comply with LA energy targets.' While the key interests of the school end-users [2] were to 'reduce energy consumption of the building and the cost of the school energy bills'. Furthermore, three types of required skills were identified during the interaction / negotiation process between the LA energy team [1] and school endusers [2]: 'communication skills' for the LA energy team to raise awareness when educating school end-users; 'project management skills' for the LA energy team to assess the appropriate EEM and oversee the project, but at the same time, lack of it; and, 'research skills' by the school end-users to contribute to the decisions surrounding the most appropriate EEMs to adopt. Through the mobilisation by the STNA and the creation of the STN, as the actors negotiated / interacted and evidenced their interests, the actor actions and, in some instances project delivery challenges, the required skills for the delivery of the energy efficient school retrofit building were highlighted.

In summary, Figure 1 shows the seven principal actors within the network and their associated 'principal' interests and required key skills in order to deliver the project.

\section{STN key actor groups and their associated principal interests and required skills}

The identified seven principal actors involved within the school retrofit project network can be further classified into three groups: the local authority (LA), the energy contractors and the school end-users (see Table 2). The LA consists of the LA energy team [1] and LA building management team [4]; the energy contractors known as the EEM surveyor [5], EEM installer [6] and EEM supplier [7]; and the school end-users [7] consist of the school head teacher, the 
[To cite this article: Bevan, W., Lu, S. and Sexton, M.G. (2020), "Skills required to deliver energy efficient school retrofit buildings", Engineering, Construction and Architectural Management, DOI: 10.1108/ECAM-03-2019-0126]

school business manager, the school site controller and pupils of the school. Table 2 summarises the key interests of the actor groups involved in the interaction and the key skills required, along with skill definitions, for the delivery of the school retrofit project.

The key results indicate that the main interests of the LA were to comply with LA energy targets; maintain an appropriate energy supply for the building; ensure an appropriate, costeffective EEM of high quality is adopted; gain EEM funding and prioritise funding to 'emergency' buildings; and hire the appropriate EEM contractor (e.g. correct skills and experience) for the job. The key interests of the energy contractors were to win the work, provide a good service for the job; gain an understanding of the EEM being implemented; gain low cost EEM options; and provide EEM information to EEM contractors and the school endusers. The school end-users' interests were to reduce energy consumption and energy costs for the school building; maintain a suitable energy supply for the building; gain knowledge on the EEM and understand how to work the EEM; and ensure the measure is installed with the least disruption possible. Taking the LA's interests as an example; one of the LA's interest to 'prioritise funding allocation to 'emergency' LA buildings and gain further funding for the EEM' emerged from both the LA energy team's [1] interest of 'gain information on the EEM funding and gain EEM funding for the school', and the LA building management team's [4] interest of 'prioritise funding allocation to 'emergency' LA buildings'. A coding schema table (see Table 2) shows how the interviews and observations resulted in the findings and where each of the skills identified came from during the interaction between [1] LA energy team and [2] School-end users. 
[To cite this article: Bevan, W., Lu, S. and Sexton, M.G. (2020), "Skills required to deliver energy efficient school retrofit buildings", Engineering, Construction and Architectural Management, DOI: 10.1108/ECAM-03-2019-0126]

Table 2: Coding schema - an example of interaction between [1] LA energy team and [2] School end-users

\begin{tabular}{|c|c|c|c|c|c|c|}
\hline $\begin{array}{l}\text { Key } \\
\text { actor }\end{array}$ & Key interest & Examples of actor interests & $\begin{array}{l}\text { Actor skills } \\
\text { required }\end{array}$ & Examples of actor skills required & Skills gaps & $\begin{array}{c}\text { Examples of } \\
\text { actor skills gap }\end{array}$ \\
\hline $\begin{array}{l}\text { [1] LA } \\
\text { energy } \\
\text { team }\end{array}$ & $\begin{array}{l}\text { - Reduce the } \\
\text { energy } \\
\text { consumption } \\
\text { of the building } \\
\text { to comply } \\
\text { with LA } \\
\text { energy } \\
\text { targets }\end{array}$ & $\begin{array}{l}\text { - "So if we can save them } \\
\text { [schools] money that's great } \\
\text { but we also save them } \\
\text { energy even better for us to } \\
\text { meet our targets... we need } \\
\text { to make sure they are energy } \\
\text { efficient products..." (Energy } \\
\text { officer) }\end{array}$ & $\begin{array}{l}\text { - Communication } \\
\text { skills: raise } \\
\text { awareness } \\
\text { when educating } \\
\text { end-users on } \\
\text { the EEM } \\
\text { - Project } \\
\text { management } \\
\text { skills: assess } \\
\text { EEM measures }\end{array}$ & $\begin{array}{l}\text { - "...it's all about energy education, the } \\
\text { same in schools as well...l get the children } \\
\text { to be as interactive as possible." (Energy } \\
\text { assistant) (communication skills) } \\
\text { - "[A PM skill] is a big thing, its problematic, } \\
\text { its hard work... There are all sorts of if, } \\
\text { buts and maybes, towards if you rip the } \\
\text { product out what is behind it you know. So } \\
\text { how are you going to pay? What are you } \\
\text { going to do to make sure the school } \\
\text { services as in the kids are not interrupted? } \\
\text { Are you going to do it when the school is } \\
\text { there, are you going to do it in half term... } \\
\text { that PM is something you have to do, you } \\
\text { can't rely on the contractors." (Energy } \\
\text { officer) (project management skills) }\end{array}$ & $\begin{array}{l}\text { - Project } \\
\text { management } \\
\text { skills }\end{array}$ & $\begin{array}{l}\text { - "As I don't have } \\
\text { skills in project } \\
\text { management, I } \\
\text { can't fully get } \\
\text { involved in any } \\
\text { project." } \\
\text { (Energy } \\
\text { assistant) }\end{array}$ \\
\hline $\begin{array}{l}\text { [2] } \\
\text { School } \\
\text { end- } \\
\text { users }\end{array}$ & $\begin{array}{l}\text { - } \text { Reduce } \\
\text { energy } \\
\text { consumption } \\
\text { and energy } \\
\text { costs of the } \\
\text { building }\end{array}$ & $\begin{array}{l}\text { - Observation between LA } \\
\text { energy officer and school } \\
\text { headmaster. Advice provided } \\
\text { in terms of EEM adoption } \\
\text { - "We have our new heating } \\
\text { system now that is more } \\
\text { energy efficient." (School site } \\
\text { controller) } \\
\text { "I found it [working in energy } \\
\text { and with the schools] } \\
\text { interesting and enjoyed going } \\
\text { around the schools and } \\
\text { showing them how to save } \\
\text { energy, and ultimately money } \\
\text { as well. All schools are up } \\
\text { against it financially so it's } \\
\text { great." (Energy assistant) }\end{array}$ & $\begin{array}{l}\text { Research skills: } \\
\text { decide on the } \\
\text { EEM for } \\
\text { implementation } \\
\text { and use }\end{array}$ & $\begin{array}{l}\text { [In response the skills used or future skills } \\
\text { required] "Well certainly research skills, I } \\
\text { think looking at alternatives...the internet is } \\
\text { certainly always the starting } \\
\text { point...Google, and then picking the brains } \\
\text { of people who come in for the quotes. You } \\
\text { know, you ask them questions and you } \\
\text { learn from them as well. It is almost free } \\
\text { advice isn't it?" (School business manager) } \\
\text { (research skills) }\end{array}$ & $\mathrm{N} / \mathrm{A}$ & $\mathrm{N} / \mathrm{A}$ \\
\hline
\end{tabular}


[To cite this article: Bevan, W., Lu, S. and Sexton, M.G. (2020), "Skills required to deliver energy efficient school retrofit buildings", Engineering, Construction and Architectural Management, DOI: 10.1108/ECAM-03-2019-0126]

It was the above interests of the key actors / actor groups that further encouraged actor interactions and negotiations within the STN, which evidenced the key skills required for the school retrofit project. The skill definitions become evident through the primary data, primarily the interviews, where actors elaborated on their actions associated with each of the required skills (see Table 3 below). It was found that the required primary skills identified for the LA were energy management skills, project management skills and communication skills; the energy contractors required technical skills and communication skills; and the school end-users required communication skills and research skills. Taking the required skills by the LA as another example; it was key interest of the LA to reduce energy consumption within the school building through understanding energy use within the school, in addition to gaining information in terms of funding, energy contractor and EEM details. These interests support the need and use of energy management skills and communication skills by the LA.

\section{Development of required skills}

The key results reveal training (both formal and informal) for the development of skills required was essential. 'Formal training' was found to be primarily associated with the EEM integration in the form of information provided to energy contractors surrounding the tools for EEM installation. This was evidenced by the solar PV supplier who expressed: "... we give a lot of training, marketing support and sales support ... we support the partners [installers] with training and given the talks to be able to answer those questions." 
[To cite this article: Bevan, W., Lu, S. and Sexton, M.G. (2020), "Skills required to deliver energy efficient school retrofit buildings", Engineering, Construction and Architectural Management, DOI: 10.1108/ECAM-03-2019-0126]

Table 3: Key interests and required skills for each actor group

\begin{tabular}{|c|c|c|c|c|}
\hline $\begin{array}{l}\text { Key actor } \\
\text { group }\end{array}$ & Key actor group's interest & Key actor & Key actor's interests & Required skills and definitions \\
\hline \multirow[t]{2}{*}{$\begin{array}{l}\text { Local } \\
\text { authority } \\
\text { (LA) }\end{array}$} & \multirow{2}{*}{$\begin{array}{l}\text { - Reduce the energy } \\
\text { consumption of the } \\
\text { building to comply with } \\
\text { LA energy targets. } \\
\text { - Maintain an appropriate } \\
\text { energy supply for the } \\
\text { building. } \\
\text { - Ensure the energy } \\
\text { efficient measure (EEM) } \\
\text { is cost-effective (i.e. low } \\
\text { cost options adopted) } \\
\text { and of high quality. } \\
\text { - Prioritise funding } \\
\text { allocation to } \\
\text { 'emergency' LA } \\
\text { buildings and gain } \\
\text { further funding for the } \\
\text { EEM. } \\
\text { - Hire EEM contractors } \\
\text { with the correct skills } \\
\text { and experience to carry } \\
\text { out the work. }\end{array}$} & $\begin{array}{l}\text { [1] LA } \\
\text { energy } \\
\text { team }\end{array}$ & $\begin{array}{l}\text { - Reduce the energy consumption of } \\
\text { the building to comply with LA } \\
\text { energy targets. } \\
\text { - Encourage energy efficiency and } \\
\text { reduce energy costs for the school. } \\
\text { - Provide energy education for the } \\
\text { school. } \\
\text { - Gain information on the EEM funding } \\
\text { and gain EEM funding for the school. } \\
\text { - Ensure the EEM is cost-effective (i.e. } \\
\text { low cost options adopted) and of } \\
\text { high quality. } \\
\text { - Gain an accurate and extensive } \\
\text { survey of the EEM required. } \\
\text { - Hire EEM contractors with the } \\
\text { correct skills and experience to carry } \\
\text { out the work. }\end{array}$ & \multirow[t]{2}{*}{$\begin{array}{l}\text { - Energy management skills: the ability } \\
\text { to carry out an energy audit and an } \\
\text { understanding of the EEM to assess } \\
\text { adoption. } \\
\text { - Communication skills: the ability to } \\
\text { interact and convey information to } \\
\text { other actors / actor groups involved } \\
\text { in the project. } \\
\text { - Project management skills: the ability } \\
\text { to organise and co-ordinate the } \\
\text { entire project from the initial } \\
\text { planning stages, the EEM design and } \\
\text { implementation, to the post } \\
\text { completion for each EEM. }\end{array}$} \\
\hline & & $\begin{array}{l}\text { [4] LA } \\
\text { building } \\
\text { manage- } \\
\text { ment } \\
\text { team }\end{array}$ & $\begin{array}{l}\text { - Ensure the building has appropriate } \\
\text { heating and electrical supply. } \\
\text { - Prioritise funding allocation to } \\
\text { 'emergency' LA buildings. }\end{array}$ & \\
\hline \multirow[t]{3}{*}{$\begin{array}{l}\text { Energy } \\
\text { contractors }\end{array}$} & \multirow{3}{*}{$\begin{array}{l}\text { - Gain an understanding } \\
\text { of the EEM for their job } \\
\text { role within the project. } \\
\text { - Win the work and } \\
\text { provide a good service } \\
\text { for future work. } \\
\text { - Gain EEM materials, low } \\
\text { cost options and } \\
\text { knowledge of the EEM } \\
\text { products. } \\
\text { - Provide EEM } \\
\text { information to EEM } \\
\text { contractors (e.g. } \\
\text { accredited installers) } \\
\text { and the school end- } \\
\text { users. }\end{array}$} & $\begin{array}{l}\text { [5] EEM } \\
\text { surveyor }\end{array}$ & $\begin{array}{l}\text { - Win the work. } \\
\text { - Carry out the EEM survey. } \\
\text { - Carry out a proper job for future } \\
\text { work. } \\
\text { - Provide EEM information to energy } \\
\text { contractors (e.g. accredited } \\
\text { installers) and the school end-users. }\end{array}$ & \multirow[t]{3}{*}{$\begin{array}{l}\text { - Technical skills: the ability to } \\
\text { understand and install the EEM, and } \\
\text { knowledge of how to use the } \\
\text { appropriate tools for the EEM survey, } \\
\text { design and installation. } \\
\text { - Communication skills: see above. }\end{array}$} \\
\hline & & $\begin{array}{l}\text { [6] EEM } \\
\text { installer }\end{array}$ & $\begin{array}{l}\text { - Win the work. } \\
\text { - Gain appropriate information from } \\
\text { the EEM surveyor for the EEM to be } \\
\text { installed. } \\
\text { - Gain the correct materials for the } \\
\text { EEM and low cost options. } \\
\text { - Gain knowledge of the EEM } \\
\text { products. } \\
\text { - Fit the EEM. } \\
\text { - Provide a good service for future } \\
\text { work with the local authority. }\end{array}$ & \\
\hline & & $\begin{array}{l}\text { [7] EEM } \\
\text { supplier }\end{array}$ & $\begin{array}{l}\text { - Supply EEM materials to accredited } \\
\text { installers. } \\
\text { - Provide information on the products } \\
\text { / EEM. }\end{array}$ & \\
\hline $\begin{array}{l}\text { School } \\
\text { end-users }\end{array}$ & $\begin{array}{l}\text { - Reduce energy } \\
\text { consumption and } \\
\text { energy costs of the } \\
\text { building. } \\
\text { - Gain the appropriate } \\
\text { EEM for the building. } \\
\text { - Maintain / gain a } \\
\text { suitable energy supply } \\
\text { for the building. } \\
\text { - Gain knowledge on the } \\
\text { EEM and understand } \\
\text { how to work the EEM } \\
\text { system. } \\
\text { - Ensure the EEM is } \\
\text { installed with the least } \\
\text { disruption possible. }\end{array}$ & $\begin{array}{l}\text { [2] } \\
\text { School } \\
\text { end- } \\
\text { users }\end{array}$ & $\begin{array}{l}\text { - Reduce energy consumption and } \\
\text { energy costs of the building. } \\
\text { - Gain the appropriate EEM for the } \\
\text { building. } \\
\text { - Maintain / gain a suitable energy } \\
\text { supply for the building. } \\
\text { - Gain knowledge on the EEM and } \\
\text { understand how to work the EEM } \\
\text { system. } \\
\text { - Ensure the EEM is installed with the } \\
\text { least disruption possible. }\end{array}$ & $\begin{array}{l}\text { - Communication skills: see above. } \\
\text { - Research skills: the ability to } \\
\text { independently investigate a potential } \\
\text { EEM and a range of appropriate EEM } \\
\text { options for adoption, and further } \\
\text { explore to gain an understanding of } \\
\text { how to operate the adopted EEM } \\
\text { components and system. } \\
\text { - Project management skills: the ability } \\
\text { to carry out the sourcing, costing and } \\
\text { management of the EEM being } \\
\text { installed and the energy contractors. } \\
\text { Basic IT skills to operate the EEM } \\
\text { adopted: the ability to operate the } \\
\text { EEM, and understand the installed } \\
\text { components required to make } \\
\text { changes, and further maintain the } \\
\text { adopted EEM and system. }\end{array}$ \\
\hline
\end{tabular}


[To cite this article: Bevan, W., Lu, S. and Sexton, M.G. (2020), "Skills required to deliver energy efficient school retrofit buildings", Engineering, Construction and Architectural Management, DOI: 10.1108/ECAM-03-2019-0126]

Furthermore, the view that training can be formal and informal was also evident. The school end-users, for example, pointed out the need for formal energy education and informal conversations to gain the required skills to adopt the EEM. Conversations providing more information were found to centre on understanding the use of the EEM for school end-users and were captured by the school business manager who mentioned: "[we learn by] picking the brains of people who come in for the quotes... you ask them questions and you learn from them as well. It is almost free advice isn't it?" This view was further supported by the LA energy assistant who stated: “...it's all about energy education, the same in schools as well ... I get the children to be as interactive as possible." The discussion above suggests the significance of appropriate learning environments that may relate to the different actor groups or the type of skills that require development.

\section{Discussion}

\section{Key actors / actor groups and interests}

The research focus on a school retrofit project and application of the STNA provided the identification of key actors / actor groups (e.g. the local authority, the energy contractors and the school end-users) involved in the delivery of an energy efficient building and their primary associated interests. The main interests for each of the three key actor groups can be found in Table 3. It was the key actors / actor groups' interests that further highlight the required skills evidenced and skill definitions within Table 3.

\section{Key actor groups' skills}

The recognition of actor group interests and negotiations within the STN gave further insight into the required skills for the delivery of the energy efficient building and associated 
[To cite this article: Bevan, W., Lu, S. and Sexton, M.G. (2020), "Skills required to deliver energy efficient school retrofit buildings", Engineering, Construction and Architectural Management, DOI: 10.1108/ECAM-03-2019-0126]

challenges (e.g. the need and methods to develop the required skills), i.e. the primary skills required identified for the LA were energy management skills, project management skills and communication skills; the energy contractors required technical skills and communication skills; and the school end-users required communication skills and research skills (see Table 2). The research also evidenced 'communication skills' were needed by all three key actor groups, where the definition is similar to the work by Zuo et al. (2018), i.e. the effective communication of information to actors within the project. Communication skills were also described as having similar characteristics by actors involved in the project. In contrast, 'technical skills' were unique to a particular actor group. The definition of technical skills, however, was in agreement with existing literature (Killip et al. 2020), where the skills were linked to a knowledge or understanding of a type of technology. For further comparison, the results indicated diverse ideas and meanings associated with the required skills by key actors. 'Project management skills' encompassed diverse actions and responsibilities by different actors during the delivery of the school retrofit project. In connection to the existing skills literature (Aggarwal et al. 2007, CBI 2013), there is evidence of the association of a skill to the roles and activities carried out by the actor. The definition of project management skills was described as the organisation, costing, co-ordination and management actions by the actors involved in the project.

Following the acknowledgement of the required skills in order to deliver the school retrofit project, the demand for training required by actors / actor groups was evident, which resonates with the existing literature (HM Government 2010). The importance of actor / actor group roles and actions for the training also became apparent in order to progress skill development to deliver the energy efficient building. More importantly, the STN highlighted the value of interactions between actors / actor groups to provide formal and informal training within the school retrofit project network. It was these mechanisms between actors, such as the 
[To cite this article: Bevan, W., Lu, S. and Sexton, M.G. (2020), "Skills required to deliver energy efficient school retrofit buildings", Engineering, Construction and Architectural Management, DOI: 10.1108/ECAM-03-2019-0126]

communication within the LA energy team, along with the engagement by the LA, energy contractors and school end-users, which were crucial to skill development during the delivery of the energy efficient school building. The interactions between the LA energy team with key actors / actor groups within the STN, along with the communication and support by the LA (the energy team and building management team) to drive the school retrofit project, further emphasise the crucial role of the LA. Similar are the findings by Killip et al. (2020), which acknowledges the importance of actor interaction for skill development through formal and informal training. Finally, similar to ideas within the existing literature (SDC 2010, Home Building Skills 2013), the need for training was experienced by all key actor groups involved in the project.

In reference to the required skills being that of 'green' skills, the views and actions involved with 'technical skills' and 'energy management skills', similar to previous building retrofit reports (Killip 2008), captured a connection to the need for knowledge and understanding of the EEM adopted and in many instances, the use of specific tools during the EEM integration.

Due to the connection to the EEM and similar to the ideas of green skills within the literature (Energy UK 2014), there are indications both technical skills and energy management skills can be associated with that of a green skill. Moreover, similar to the discussion of a green skill within the literature (Aldersgate Group 2009), there appears to be the connection to renewable technology, i.e. the link of green skills to EEM adoption. Finally, as there was evidence of technical skills and energy management skills needed to understand the use of the building, the findings relate to the existing ideas for 'low carbon' skills (Construction Skills 2011).

The need for training (both formal and informal) to gain the required skills by the construction sector and its clients further demonstrated that 'new' skills are required for the energy efficient building delivery. There were also indications, however, that training was facilitating an upskilling of the workforce. Finally, the required skills that were connected to 'green' skills were 
[To cite this article: Bevan, W., Lu, S. and Sexton, M.G. (2020), "Skills required to deliver energy efficient school retrofit buildings", Engineering, Construction and Architectural Management, DOI: 10.1108/ECAM-03-2019-0126]

not only required skills where actors needed training (i.e. skill development), but also occurred for existing skills or more generic skills.

\section{Conclusions}

\section{Empirical contribution}

The prevailing literature argues the need for 'new' skills to deliver energy efficient buildings. The concept of 'new' skills, however, has not been subject to empirical investigation. The findings provide two distinct empirical contributions. First, the results have contested the common view of homogenous skill sets and presented a more complex picture of the required skills for the delivery of energy efficient school retrofit buildings that is highly contingent on the actor groups and the different phases of the project (planning, design, installation and postcompletion phase). The complexity of the required skills was further evidenced through its connection of 'green' skills and the need for training for actors to deliver the energy efficient building project, which can be linked to the development of 'new' skills and improvement of 'existing' skills. Indeed, it was found that skill development was required for those skills that were linked to 'green' skills, e.g. 'energy management skills,' along with those skills that were generic to a building project and where an up-skilling of the construction sector and its clients was of value e.g. 'project management skills.' Second, the results reinforce the crucial champion role of the LA in the energy performance of school buildings as evidenced through the interaction between the LA and other key stakeholders involved in the project delivery process, starting from the identification of schools to deem 'emergency buildings', securing funding from the government, selecting energy contactors, and coordinating other key stakeholders to deliver the project on-site. 
[To cite this article: Bevan, W., Lu, S. and Sexton, M.G. (2020), "Skills required to deliver energy efficient school retrofit buildings", Engineering, Construction and Architectural Management, DOI: 10.1108/ECAM-03-2019-0126]

\section{Theoretical contribution}

The empirical contributions that the development of the required skills for the delivery of energy efficient school buildings emerge from the socio-technical interactions of the project network, further provides associated theoretical contributions. First, it lends support to the contention that the identification of the development of appropriate construction skills requires various actors to work collaboratively (Grugulis 2003, Construction Skills 2010, RIBA 2015). The present study builds upon the prevailing literature to offer empirical evidence for the type of project actor interactions and how skill development works in practice. Second, the study offers a micro-level perspective on skill development at a project-level. The micro-dynamic perspective advances current literature that tends to explore construction skill challenges and skill development primarily at a macro, sector-level (Home Building Skills 2013, Hogarth and Gambin 2014). The study of a specific building project was able to offer detail and definitions on the type of skills required, and further explore the interactions and more complex negotiations of project actors associated with formal and informal types of training. Finally, the current literature tends to privilege the more technical elements associated with 'new' skills and 'green' skills required for the delivery of energy efficient buildings (RIBA 2008, Construction Skills 2011), arguing that the lack of these skills are the central problem. The current study, though, gave attention to the equal importance of the more generic skills for the delivery of energy efficient school buildings.

\section{Contribution to practice}

The results reveal the need for the construction industry and its clients to recognise the complex skills set required for the delivery of energy efficient school retrofit buildings, more specifically, the importance of both 'generic' skills (e.g. communication skills) and 'green' skills (e.g. energy management skills), as oppose to solely 'green' skills - a recommendation 
[To cite this article: Bevan, W., Lu, S. and Sexton, M.G. (2020), "Skills required to deliver energy efficient school retrofit buildings", Engineering, Construction and Architectural Management, DOI: 10.1108/ECAM-03-2019-0126]

proposed in the extant literature (RIBA 2008, Jagger et al. 2012). The construction skills councils and professional training bodies in particular would benefit from the findings in regards to greater understanding of the need to provide training for the construction industry and its clients to gain and enhance both skills set. Similarly, the actors involved in the delivery of the energy efficient building may need to gain 'new' skills that can be known as 'green' skills, but also those of a more generic nature. The construction sector and its clients may further benefit through recognition of various types of skills development available (e.g. formal and informal), in particular the importance of interactions between the key stakeholders involved in the retrofit of energy efficient school buildings which can contribute the skill development process, e.g. learning by doing.

\section{Implications for method}

The focus on the STN provided details of the empirical setting, but further highlighted the complexity that can be associated with actor / actor group identification and the challenge of how to represent project actors within the network. The application of the STNA not only allowed the identification of actors / actor groups within the network, but different interpretative flexibilities between actors / actor groups were also of significance to gain insight into negotiations. It was these interactions and negotiations that represented the required skills for the delivery of energy efficient buildings, in addition to the decisions and actions that were essential for actor skill development. Furthermore, the STNA reveals the intermediaries between actors / actor groups. These exchanges were valuable to enhance the detail of the skill development undertaken. The exchange of training documents, such as solar energy manuals, for example, provided insight on the nature of the training (formal / informal) and the process between actors / actor groups. Furthermore, as highlighted by Schweber and Harty (2010), interpretative flexibilities offer understanding for reasons behind the stable / unstable nature of the network through the representation of negotiations. The results yield significant 
[To cite this article: Bevan, W., Lu, S. and Sexton, M.G. (2020), "Skills required to deliver energy efficient school retrofit buildings", Engineering, Construction and Architectural Management, DOI: 10.1108/ECAM-03-2019-0126]

implications in understanding the role of the STN to demonstrate heterogeneity in the articulation and enactment of skills in the delivery of energy efficient buildings.

\section{Implications for policy}

The findings give further empirical weight that LAs have a significant leadership role in the retrofit of school buildings (UK Green Building Council 2017) and to deliver sustainable buildings ( $\mathrm{Li}$ et al. 2019). The research also identifies the importance of project management skills and at the same time, lack of such skills for the LAs, and the need for further education and training in these areas. Implications lie with the ability for the LA to gain the required training. Moreover, construction professional bodies (e.g. RIBA, CIOB) and sector skills councils (e.g. Construction Skills) need to compliment training for 'new' skills and 'green' skills with the development of 'generic' skills (in particular project management skills and communication skills) required for the delivery of energy efficient buildings.

\section{Future areas of research}

Two potential areas for future research. First, the research recognises the limitations of a single case study (i.e. one local authority) (see the 'Research design and methods / limitations of a single case study' section for further detail). To enhance the credibility of, and possibly extend the research findings, it would be of benefit to explore another case or multiple case studies, such as a different local authority involved in the delivery of energy efficient school retrofit buildings. This may provide insight into various local level policy drivers (e.g. energy reduction targets) or approaches (e.g. the use of preferred or local suppliers) the local authority set up to meet, and in turn providing further insights into types of EEMs being adopted, and the diverse skills required for the delivery of the retrofit of the buildings. Second, as the investigation highlighted the need for skill development and the crucial role of the local authority in driving energy performance of school buildings, further research that explores the 
[To cite this article: Bevan, W., Lu, S. and Sexton, M.G. (2020), "Skills required to deliver energy efficient school retrofit buildings", Engineering, Construction and Architectural Management, DOI: 10.1108/ECAM-03-2019-0126]

potential for the adoption of formal and informal training by the local authority specifically

would be of value.

\section{References}

Aggarwal, R., Grantcharov, T. P. and Darzi, A. (2007). Framework for systematic training and assessment of technical skills. Journal of the American College of Surgeons, 204(4), 697-705.

Aldersgate Group (2009). Mind the gap: skills for the transition to a low carbon economy, Aldersgate Group, London.

Allard-Poesi, F., Drucker-Godard, C. and Ehlinger, S. (2001), "Analyzing Representations and Discourse" in R.A. Thiétart et al. (Eds.) Doing Management Research: A Comprehensive Guide, Sage Publications: Paris, pp. 351-372.

Azizi, N.S.M., Wilkinson, S. and Fassman, E. (2015). Strategies for improving energy saving behaviour in commercial buildings in Malaysia. Engineering, Construction and Architectural Management, 22(1), 73-90.

Bird, J. and Lawton, K. (2009). The future's green: jobs and the UK low-carbon transition, Institute for public policy research, London.

Brockman, M., Clarke, L. and Winch, C. (2008). Knowledge, skills, competence: European divergences in vocational education and training (VET) - the English, German and Dutch cases. Oxford Review of Education, 34(5), 547-567.

Bryman, A. (2016). Social research methods. $5^{\text {th }}$ Edn. Oxford: Oxford University Press.

Callon, M., Rip, A. and Law, J. (Eds) (1986) Mapping the Dynamics of Science and Technology: Sociology of Science in the Real World, Palgrave Macmillan, Basingstoke, UK.

Carroll, G. and Boutall, T. (2011). Guide to Developing National Occupational Standards, accessed $11 / 08 / 2019$. Online at

https://assets.publishing.service.gov.uk/government/uploads/system/uploads/attachment_data/file/304 239/nos-guide-for-_developers-2011.pdf

CBI (Confederation of British Industry). (2013). Changing the pace: CBI / Pearson education and skills survey 2013, CBI, London.

Centre for Low Carbon Futures (2012). The retrofit challenge: delivering low carbon buildings. York, UK.

Chan, P. W. and Dainty, A. R. J. (2007). Resolving the UK construction skills crisis: a critical perspective on the research and policy agenda. Construction Management and Economics, 25(4), 375386.

CIOB (Chartered Institute Of Building). (2010). A report exploring skills in the UK construction industry. CIOB, Ascot, UK.

Clarke, L., Gleeson, C. and Winch, C. (2017). What kind of expertise is needed for low energy construction? Construction Management and Economics, 35(3), 78-89. 
[To cite this article: Bevan, W., Lu, S. and Sexton, M.G. (2020), "Skills required to deliver energy efficient school retrofit buildings", Engineering, Construction and Architectural Management, DOI: 10.1108/ECAM-03-2019-0126]

Clarke, L. and Wall, C. (1998). UK construction skills in the context of European developments. Construction Management and Economics, 16(5), 553-567.

Clarke, L., Winch, C. and Brockmann, M. (2013). Trade-based skills versus occupational capacity: the example of bricklaying in Europe. Work, Employment \& Society, 27(6), 932-951.

Climate Change Act 2008. (c. 27). London: The Stationary Office. accessed 11/07/2019. Online at: https://www.legislation.gov.uk/ukpga/2008/27/contents

Committee on Climate Change (2015). Reducing emissions and preparing for climate change: 2015 Progress Report to Parliament, London.

Construction Skills (2010). Sector Skills Assessment for the Construction Sector 2010, Construction Skills, Norfolk.

Construction skills (2011). Low carbon skills requirements for the regeneration and built environment professional services in Wales, Centre for Regeneration Excellence Wales (CREW), Wales, UK.

Dainty, A. R. J., Ison, S. G. and Briscoe, G. (2005). The construction labour market skills crisis: the perspective of small-medium-sized firms. Construction Management and Economics, 23(4), 387-398.

Dainty, A. R. J., Ison, S. G. and Root, D. S. (2004). Bridging the skills gap: a regionally driven strategy for resolving the construction labour market crisis. Engineering, Construction and Architectural Management, 11(4), 275-283.

DCLG (Department for Communities and Local Government). (2015). Improving the energy efficiency of our buildings: a guide to display energy certificates and advisory reports for public buildings, Crown Copyright, London.

DECC (Department of Energy and Climate Change). (2011). The carbon plan, Crown Copyright, London.

Downey, M. (2014), the selection and adopting of low and zero carbon technologies in social housing : a social-technical network approach, Unpublished PhD thesis, University of Reading, Reading, UK.

Edum-Fotwe, F. T. and McCaffer, R. (2000). Developing project management competency: perspectives from the construction industry. International Journal of Project Management, 18(2), 111-124.

Elle, M., Dammann, S., Lentsch, J. and Hansen, K. (2010). Learning from the social construction of environmental indicators: From the retrospective to the pro-active use of SCOT in technology development. Building and Environment, 45(1), 135-142.

Elzen, B., Enserink, B. and Smit, W. A. (1996). Socio-Technical Networks: how a technology studies approach may help to solve problems related to technical change. Social Studies of Science, 26(1), 95141.

Energy UK (2014). British Gas - green skills centre, accessed 26/08/19. Online at https://www.energy-uk.org.uk/energy-industry/lighting-up-britain/british-gas-green-skills-centre.html

EST (Energy Saving Trust) (2010). Sustainable energy in the built environment: best practice for Scottish planners, EST, Edinburgh, UK.

EST (Energy Saving Trust). (2017). Home improvements guide, accessed 25/08/2019. Online at http://www.energysavingtrust.org.uk/home-energy-efficiency/home-improvements.

Felstead, A., Gallie, D., Green, F. and Inanc, H. (2012). Skills at work in Britain: first findings from the skills and employment survey, 2012, Institute of Education, London. 
[To cite this article: Bevan, W., Lu, S. and Sexton, M.G. (2020), "Skills required to deliver energy efficient school retrofit buildings", Engineering, Construction and Architectural Management, DOI: 10.1108/ECAM-03-2019-0126]

Gann, D. and Senker, P. (1998). Construction skills training for the next millennium. Construction Management and Economics, 16(5), 569-580.

GCB (Green Construction Board) (2013). Scoping study for a low carbon existing homes or buildings support mechanism. SWEETT.

GCB (Green Construction Board) (2015), Reducing carbon reduces cost: three years on report, Green Construction Board, available at: http://www.infrastructure-

intelligence.com/sites/default/files/article_uploads/GCB\%203YO\%20report\%20final.pdf (accessed 7 July 2019)

Glass, J., Dainty, A. R. J. and Gibb, A. G. F. (2008). New build: materials, techniques, skills and innovation. Energy Policy, 36(12), 4534-4538.

Grugulis, I. (2003). The Contribution of National Vocational Qualifications to the Growth of Skills in the UK. British Journal of Industrial Relations, 41(3), 457-475.

Guba, E. G. and Lincoln, Y. S. (1981). Effective evaluation. San Francisco: Jossey-Bass Inc. Publishers.

Hammersley, M. and Gomm, R. (2000). 'Introduction' in R. Gomm, M. Hammersley and P. Foster (eds.) Case study method. London: Sage, pp. 1-16.

HM Government (Department of Business Innovation and Skills). (2010). Low carbon construction: innovation and growth team, BIS (department for business innovation and skills), London.

Hogarth, T. and Gambin, L. (2014). Employer investment in Apprenticeships in England: an exploration of the sensitivity of employers in the construction sector to the net costs of training. Construction Management and Economics, 32(9), 845-856.

Home Building Skills (2013). Home Building Skills research report 2013: preparing to deliver tomorrow's new homes, Home Building Skills, Milton Keynes.

House of Commons (2014). No more lost generations: creating construction jobs for young people. London.

Huang, Y., Niu, J. and Chung, T. (2013). Study on performance of energy-efficient retrofitting measures on commercial building external walls in commercial-dominant cities. Applied Energy, 103(1), 97-108.

Jagger, N., Foxon, T. and Gouldson, A. (2012). Skills constraints and the low carbon transition. Climate Policy, 13(1), 43-57.

Johari, S. and Jha, K. N. (2020). Challenges of attracting construction workers to skill development and training programmes. Engineering, Construction and Architectural Management, 27(2), 321-340.

Killip, G. (2008). Building a greener Britain, Federation of Master Builders, London.

Killip, G., Owen, A. and Topouzi. (2020). Exploring the practices and roles of UK construction manufacturers and merchants in relation to housing energy retrofit. Journal of Cleaner Production, 251(1), 1-12.

Klein, H. K. and Kleinman, D. L. (2002). The Social Construction of Technology: Structural Considerations. Science, Technology \& Human Values, 27(1), 28-52.

Latour, B. (1993). Have Never Been Modern Cambridge, Mass, Harvard University Press.

Law, J. and Hassard, J. (eds.) (1999). Actor Network Theory and After: Blackwell. 
[To cite this article: Bevan, W., Lu, S. and Sexton, M.G. (2020), "Skills required to deliver energy efficient school retrofit buildings", Engineering, Construction and Architectural Management, DOI: 10.1108/ECAM-03-2019-0126]

$\mathrm{Li}, \mathrm{X}$. (2019). Driving forces influencing the uptake of sustainable housing in New Zealand. Engineering, Construction and Architectural Management, 26(1), 46-65.

Lincoln, Y. S. and Guba, E. G. (2000). 'The only generalization is: there is no generalization' in R. Gomm, H. M and P. Foster (eds.) Case study method. London: Sage Publications, pp. 27-44.

Lowe, R., Chiu, L. F. and Oreszczyn, T. (2018). Socio-technical case study method in building performance evaluation. Building Research \& Information, 46(5), 469-484.

Ma, Z., Cooper, P., Daniel, D. and Ledo, L. (2012). Existing building retrofits: methodology and state-of-the-art. Energy and Buildings, 55(1), 889-902.

NHBC (National House building Council) (2014) Technical Extra: March 2014, Issue 13. NHBC, Milton Keynes, UK. available at:

http://www.nhbc.co.uk/NHBCPublications/LiteratureLibrary/Technical/TechnicalExtra/filedownload, 55428,en.pdf (accessed 10 April 2019)

OECD (Organisation for Economic Co-operation and Development). (2011). Towards an OECD skills strategy, OECD.

Pisello, A. L., Goretti, M. and Cotana, F. (2012). A method for assessing buildings' energy efficiency by dunamic simulation and experimental activity. Applied Energy, 97(1), 419-429.

QSR International (2017). NVivo Server 10 for Windows, accessed 01.12.17. Online at http://www.qsrinternational.com/nvivo/support-overview/downloads/nvivo10-for-windows.

Rawlins, J. and Marasini, R. (2011). Are the construction graduates on CIOB accredited degree courses meeting the skills required by the industry? In: Egbu, C and Lou, E C W (Eds.), Proceedings 27th Annual ARCOM Conference, 5-7 September 2011, Bristol, UK. Association of Researchers in Construction Management, 167-74.

RIBA (Royal Institute of British Architects). (2008). Skills for Low Carbon Buildings, Energy Saving Trust, London.

RIBA (Royal Institute of British Architects). (2014). Building a better Britain: a vision for the next government, UK.

RIBA (Royal Institute of British Architects). (2015). RIBA appointments skills survey report 2014, RIBA Enterprises Ltd.

RIBA (Royal Institute of British Architects). (2016). Better spaces for learning, UK.

Schweber, L. and Harty, C. (2010). Actors and objects: a socio-technical networks approach to technology uptake in the construction sector. Construction Management and Economics, 28(6), 657674.

SDC (Sustainable Development Commission). (2010). The future is local: empowering communities to improve their neighbourhoods, Sustainable Development Commission, UK.

Smith, S. (2019). New housing \& future construction skills: adapting and modernising for growth. Scottish Government, UK

The Carbon Trust (2012). Local authorities: saving energy in local authority buildings. The Carbon Trust, London, UK.

The Carbon Trust (2015). Personal communication regarding advice for the investigation. Customer centre leader. London, UK. 
[To cite this article: Bevan, W., Lu, S. and Sexton, M.G. (2020), "Skills required to deliver energy efficient school retrofit buildings", Engineering, Construction and Architectural Management, DOI: 10.1108/ECAM-03-2019-0126]

UK Green Building Council (2017). The role of local leadership in creating sustainable homes: green paper, London.

UKCES (UK Commission for Employment and Skills). (2009). Ambition 2020: world class skills and jobs for the UK, UKCES, London.

Xu, P., Chan, E. H. W., Visscher, H. J., Zhang, X. and Wu, Z. (2015). Sustainable building energy efficiency retrofit for hotel buildings using EPC mechanism in China: analytic Network Process (ANP) approach. Journal of Cleaner Production, 107(November), 378-388.

Yin, R. K. (2018). Case study research and applications: design and methods. $6^{\text {th }}$ Edn. Los Angeles: Sage Publications.

Zuo, J., Zhao, X., Nguyen, B.B.M., Ma, T. and Gao, S. (2018) Soft skills of construction project management professionals and project success factors. Engineering, Construction and Architectural Management, 25(3), 425-442. 